\title{
THE THERAPEUTIC USE OF SYMBIOTICS
}

\author{
O uso terapêutico dos simbióticos
}

\author{
Aline Gamarra Taborda FLESCH , Aline Kirjner POZIOMYCK, Daniel De Carvalho DAMIN
}

From the Programa de Pós-Graduação em Ciências Cirúrgicas, Universidade Federal do Rio Grande do Sul (Post-Graduate Surgical Sciences, Federal University of Rio Grande do Sul), Porto Alegre, RS, Brazil
ABSTRACT - Introduction: Functional foods are health promoters and their use is associated with reduced risk of chronic degenerative and non-transmissible diseases. Examples are symbiotic. The association of one (or more) probiotic with a one (or more) prebiotic is called symbiotic, being the prebiotics complementary and probiotics synergistic, thus presenting a multiplicative factor on their individual actions. Objective: To assess the evidences on the benefits of the use of symbiotics in the treatment of clinical and surgical situations. Methods: The headings symbiotic, probiotic and prebiotic were searched in Pubmed/Medline in the last 15 years, and were selected 25 articles, used for database. Results: The use of symbiotic may promote an increase in the number of bifidobacteria, glycemic control, reduction of blood cholesterol, balancing the intestinal flora which aids in reducing constipation and/or diarrhea, improves intestinal permeability and stimulation of the immune system. Clinical indications for these products has been expanded, in order to maximize the individual's physiological functions to provide greater. So, with the high interest in the clinical and nutritional control of disease, many studies have been conducted demonstrating the effectiveness of using symbiotic in improving and/or preventing various and/or symptoms of gastrointestinal diseases. Conclusion: Symbiotic behave differently and positively in various pathological situations.
HEADINGS - Prebiotics. Probiotics. Symbiotics.

\section{Correspondence:}

Aline Gamarra Taborda Flesch

E-mail: alinegamarrat@hotmail.com

Financial source: none

Conflicts of interest: none

Received for publication: $26 / 11 / 2013$

Accepted for publication: 13/05/2014

DESCRTORES - Simbiótico. Probiótico. Prebiótico.
RESUMO - Introdução: Os alimentos funcionais são vistos como promotores de saúde e seu uso está associado à redução do risco de desenvolvimento de doenças crônicas degenerativas e nãotransmissíveis. Exemplos deles são os simbióticos. A associação de um (ou mais) probiótico com um (ou mais) prebiótico denomina-se simbiótico, sendo os prebióticos complementares e sinérgicos aos probióticos, apresentando assim um fator multiplicativo sobre suas ações isoladas. Objetivo: Verificar as evidências dos benefícios do uso de simbióticos no tratamento de situações clínicas e cirúrgicas. Métodos: Foram buscados no Pubmed/Medline os descritores: simbiótico, probiótico e prebiótico nos últimos 15 anos, sendo que do universo pesquisado foram selecionados 25 artigos utilizados como base de dados. Resultados: O uso do simbiótico pode promover aumento do número de bifidobactérias, controle glicêmico, redução da taxa de colesterol sanguíneo, balanceamento da microbiota intestinal que auxilia na redução da obstipação e/ou diarréia, melhora da permeabilidade intestinal e estimulação do sistema imunológico. As indicações clínicas destes produtos tem sido ampliada, com intuito de maximizar as funções fisiológicas individuais para possibilitar o incremento da saúde. Assim, com o interesse elevado no controle clínico e nutricional das doenças, muitos estudos já foram realizados comprovando a eficácia do uso de simbióticos na melhora e/ ou prevenção de doenças diversas e/ou de sintomas gastrointestinais. Conclusão: Os simbióticos comportam-se de forma diferenciada e positiva nas mais variadas situações patológicas.

$T$ he use of symbiotics have been extensively studied and shown promising alternative for use in combination with antibiotics or isolated. Reestablish the microenvironment enhances gastrointestinal absorption and increases the immunity of patients ${ }^{10,17}$

The use of functional foods, particularly symbiotic has been incremented by diet therapy with the intention of improving the health status of patients with certain cancers. It is common the occurrence of changes in the composition of the human gastrointestinal flora which can be altered by environmental and dietary factors favoring perioperative infections ${ }^{9,12}$. The reasons why these patients are more susceptible to infections than other surgical patients are multifactorial. Among them, bacterial translocation is considered the leading cause of postoperative infection ${ }^{6}$.

Studies show that treatment with symbiotics may be good strategy in the prevention and reduction of postoperative infections. The magnitude of the effect depends on the type of symbiotic preparation and concentration of the microorganism in the compound $d^{6,15,24}$

The objective of this study was to verify the evidence of the benefits of the use of symbiotics in the treatment of clinical and surgical situations.

\section{METHOD}

For this study the literature was reviewed in Pubmed / Medline using the headings symbiotic, probiotic and prebiotic in the last 15 years; were selected 25 articles used for database. 
RESULTS

\section{Probiotics}

The FAO / WHO consider probiotics as live microorganisms which when administered in adequate doses, confer health benefits to the host. Among the beneficial effects can be highlighted: relief of symptoms caused by lactose intolerance, treatment of diarrhea, decreased serum cholesterol, increased immune response and anticarcinogenic effect ${ }^{19}$

Rafter et al. ${ }^{14}$ suggest several mechanisms of action. The main explanation are: stimulation of the host immune response (by increasing phagocytic activity, the synthesis of IgA and activation of $\mathrm{T}$ and $\mathrm{B}$ lymphocytes); binding and degradation of compounds with carcinogenic potential; qualitative and/or quantitative changes in intestinal microbiota involved in the production of carcinogens; antimutagenic producing compounds in the colon (like butyrate); change in the metabolic activity of the intestinal microbiota; alteration of physicochemical conditions of the colon with decreasing $\mathrm{pH}_{i}$ and effects on the host physiology 2, 5,14,19.

Probiotics may contain fully understood and quantified bacteria or bacterial cultures not defined. Enterococcus, Bacteroides, Eubacterium and especially Lactobacillus and Bifidobacterium are present in all cultures. On the other hand, one does not know the ideal composition that best stimulates probiotic properties "in vivo". Products with crops not defined have the best probiotic action that those with defined cultures ${ }^{4,9.17}$.

Lactobacilli are facultative, predominant in the small intestine gram-positive and anaerobic bacteria. Among its species can be cited Lactobacillus casei, Lactobacillus rhamnosus, Lactobacillus acidophilus ${ }^{13}$. Lactobacilli inhibit proliferation of non-beneficial microorganisms, by competing with binding sites and nutrients and producing organic acids that reduce intestinal $\mathrm{pH}$, slowing the growth of pathogenic bacteria ${ }^{12}$. The bifidobacteria are strict anaerobic or anaerobic normally prevalent in the large intestine and have beneficial role in cases of diarrhea (Figure 1 ).

FIGURE 1 - Applicability of microorganisms Lactobacillus casei, Lactobacillus rhamnosus, Lactobacillus acidophilus and Bifidobacterium lactis in clinical situations

\begin{tabular}{|c|c|}
\hline Strains & Clinical situations \\
\hline $\begin{array}{l}\text { Lactobacillus } \\
\text { casei }\end{array}$ & $\begin{array}{l}\text { - Prevention of antibiotic-associated diarrhea in grown ups } \\
\text { - Prevention of diarrhea by C. difficile in adults } \\
\text { - Adjuvant therapy for } H \text {. pylori eradication } \\
\text { - Complements the growth of Lactobacillus acidophilus } \\
\text { - Helps in digestion and reduce lactose intolerance } \\
\text { and constipation }\end{array}$ \\
\hline $\begin{array}{l}\text { Lactobacillus } \\
\text { acidophilus }\end{array}$ & $\begin{array}{l}\text { - Prevention of necrotizing enterocolitis in infants pre-mature } \\
\text { - Prevention of diarrhea by C. difficile in adults } \\
\text { - Prevention of antibiotic-associated diarrhea in grown ups } \\
\text { - Treatment of acute infectious diarrhea in children } \\
\text { - Produces lactase enzyme } \\
\text { - Increases immunity }\end{array}$ \\
\hline $\begin{array}{l}\text { Lactobacillus } \\
\text { rhamnosus }\end{array}$ & $\begin{array}{l}\text { - Treatment of acute infectious diarrhea in children } \\
\text { - Prevention of antibiotic-associated diarrhea in children } \\
\text { - Prevention of antibiotic-associated diarrhea in } \\
\text { grown ups } \\
\text { - Prevention of diarrhea in children nasocomial } \\
\text { - Adjuvant therapy for } \mathrm{H} \text {. pylori eradication } \\
\text { - Relieves some symptoms of irritable bowel } \\
\text { syndrome }\end{array}$ \\
\hline $\begin{array}{l}\text { Bifidobacterium } \\
\text { lactis }\end{array}$ & $\begin{array}{l}\text { - Prevention of necrotizing enterocolitis in infants } \\
\text { pre-mature } \\
\text { - Prevention of diarrhea by C. difficile in adults } \\
\text { - Prevention and maintenance of remission in pouchit }\end{array}$ \\
\hline
\end{tabular}

\section{Prebiotics}

The term prebiotic was employed by Gibson and Roberfroid in 1995 to describe "non-digestible nutritional ingredients that beneficially affect the host selectively stimulating the growth and activity of one or more beneficial bacteria in the colon, improving the health of its host" ${ }^{15}$. The primary action is to stimulate their growth and/or activating the metabolism of some group of beneficial bacteria in the intestinal tract. Thus, prebiotics act closely related to probiotics as "food" of the probiotic bacteria ${ }^{3,13}$.

\section{General characteristics of prebiotics}

Should not be metabolized or absorbed during its passage through the upper digestive tract; should serve as a substrate for one or more beneficial intestinal bacteria (these are stimulated to grow and/or become metabolically active); possess the ability to alter the intestinal microflora in a favorable manner to the health of the host; induce systemic or intestinal lumen of the host beneficial effects.

\section{Prebiotic substances}

Some or non-absorbable sugars, fiber, oligosaccharides and sugar alcohols are in this concept of prebiotics. Of these, the oligosaccharides - short chains of polysaccharide compounds from three to 10 simple sugars linked together -, have received more attention by numerous prebiotic properties assigned to them ${ }^{13,23}$.

The fructooligosaccharides are polysaccharides which have demonstrated good prebiotic effects, "feeding" selectively and some species of Lactobacillus and Bifidobacterium, thus reducing the amount of other bacteria such as Bacteroides, Clostridium and coliforms ${ }^{3.23}$.

Prebiotics can be generated naturally in seeds and roots of some plants such as chicory, onions, garlic, artichokes, asparagus, barley, rye, soy beans, chick-peas and lupins. Can also be extracted by cooking or by enzymatic action or alcoholic. There are also synthetic oligosaccharides obtained by direct polymerization of disaccharides some cell wall polysaccharides of yeast and fermentation. The synthetic oligosaccharides have shown better results as prebiotics and fewer side effects ${ }^{11,22,23}$.

The prebiotic substances stimulate the growth of beneficial intestinal bacteria number whose metabolic also act reducing the $\mathrm{pH}$ by increasing the amount of organic acids. It is speculated that the oligosaccharides may also act by stimulating the immune system by indirect reduction of intestinal translocation by pathogens which would determine infections after reaching the bloodstream ${ }^{13.23}$.

\section{Symbiotic}

Symbiotics are composed of live microorganisms which when administered in adequate doses, can benefit the health of the host. They are formed by the association of one or more probiotics with one or more prebiotics. Prebiotics are complementary and synergistic to probiotics, thus presenting multiplier on their isolated actions ${ }^{1}$. This combination should enable the survival of probiotic bacteria in food and conditions of the gastric medium. Allowing its action in the large intestine, and the effects of these ingredients can be added or synergistic ${ }^{13}$.

Among the functions of symbiotic strains, increased resistance against pathogens is the best characterized. The use of probiotic cultures exclude potentially pathogenic microorganisms which are growth inhibited by the production of organic acids (lactate, propionate, butyrate and acetate) and bacteriocins, enhancing natural defense mechanisms. A modulation of intestinal microbiota by probiotic microorganisms occurs through the mechanism called "competitive exclusion" and the strains that influence beneficially in these cases are Bifidobacterium bifidum, 
Lactobacillus rhamnosus, Saccharomyces boulardii and Lactobacillus plantarum ${ }^{8}$.

Another relevant factor is the clinical intestinal barrier, since malnourished patients usually have losses in the balance of the intestinal barrier. The intestinal microflora is an important constituent of the intestinal barrier defense by promoting local immune response and systemic level, with intense inflammatory response. The use of symbiotic optimizes the intestinal immune system and promotes the control of flora, decreasing the incidence of infection due to probiotics increase the circulating lymphocytes and cytokines, which stimulate phagocytosis. Prebiotics in turn increase the release of high levels of lactic acid and consequently promote lowering of colonic $\mathrm{pH}^{4.19}$.

The action of microorganisms, mainly bifidobacteria in the digestive tract, favorably influences the amount, bioavailability and digestibility of some nutrients in the diet. This occurs by decreasing intestinal $\mathrm{pH}$ or the presence of lactate of iron in the intestine or by release, by lactic acid bacteria, various enzymes in the intestinal lumen to exert synergistic effects on digestion, relieving symptoms of deficient absorption of various nutrients between which are calcium, magnesium and iron, common framework in patients with chronic pancreatitis ${ }^{18}$.

The use of symbiotic leads to increased absorption of calcium and, probably, the mechanism of this optimization should be the increased $\mathrm{pH}$ and influence on the intestinal absorption of phosphorus and magnesium. Stimulation of calcium absorption occurs when prebiotic substances are fermented in the colon by the local microflora, especially bifidobacteria, producing gases, organic acids and short chain fatty acids. These short-chain fatty acids are responsible for decreasing the $\mathrm{pH}$ of the intestinal lumen, causing an increase in the concentration of ionized minerals and, as a consequence, there is an increase in the solubility of calcium and its subsequent challenge active and passive diffusion ${ }^{18}$.

The increase the bioavailability of the iron appears to be explained by the decrease of the intestinal $\mathrm{pH}$ due to the presence of fermentation products (proponate, butyrate and acetate) of bifidobacteria that cause solubilization of the minerals and their preformed complexes, increasing the absorption of solubilized iron which is better absorbed by the brush border of the enterocytes ${ }^{20}$.

Other hypotheses for this improvement in iron absorption can be raised, as the presence of lactate of iron, derived from lactic acid produced by probiotics, which is better absorbed by the cell membranes of the ionized iron; increasing the bioavailability of iron can even be correlated with increased calcium absorption, which decreases the possibility of forming insoluble complexes between this mineral and iron; and yet the fact of probiotics increase of intestinal transit time ${ }^{20}$.

Regarding the presence of diarrhea are expected to operate with a symbiotic probiotic portion, to exclude pathogenic bacteria through competition for the binding sites on the intestinal mucosa, as well as preventing the adhesion of pathogenic bacteria to the intestinal mucosa; and their prebiotic portion, with the action of FOS, through the selective action mechanism, only promotes growth of bifidobacteria and thus helps in the balance of intestinal microbiota $^{18}$

The effect of inulin and FOS administration on blood glucose and insulin has not been definitively elucidated and the data available; in this regard, they are sometimes contradictory, indicating that these effects depend on the physiological condition as fasting or postprandial state or presence of diabetes. However, the studies that bring in common is the observation that inulin and FOS influence the absorption of nutrients, especially carbohydrates, slowing gastric emptying and/or decreasing the transit time in the small intestine ${ }^{8}$.

The use of symbiotic, among other benefits, may increase the number of bifidobacteria, glycemic control, reduction of blood cholesterol, balance of healthy intestinal flora which aids in reducing constipation and/or diarrhea, improves intestinal permeability and stimulates immune system ${ }^{25}$.

Symbiotic therefore provide the joint action of probiotics and prebiotics, which can be classified as functional dietary components that may enhance survival of probiotics during its passage through the upper digestive tract, because of its specific substrate be available for fermentation ${ }^{10}$.

\section{Dosage for the use of symbiotic}

According to the Technical Regulations 2005 ANVISA probiotic portion of a symbiotic must have minimum viable amount in the range 108-109 CFU in the daily recommendation of the product ready for consumption. The concentration of viable cells should be adjusted in the initial preparation, taking into account the survivability in order to reach the minimum of $107 \mathrm{CFU}$ of intestinal contents ${ }^{21}$. In Table 1 can be observed the recommended dose (CFU) of more used probiotics.

TABLE 1 - Recommended doses based on evidence of the most used probiotics

\begin{tabular}{ll} 
Strains & Amount \\
\hline Lactobacillus casei & $10^{10}$ ufc -2 xday \\
\hline Lactobacillus acidophilus & $10^{9}-10^{10}$ ufc -1 a 3 x/day \\
Lactobacillus rhamnosus & $10^{10}-10^{11}$ ufc -2 x/day \\
Bifidobacterium lactis & 1010 ufc -2 xday
\end{tabular}

Source: Adapted from "evidence-based indications of probiotics and prebiotics in gastroenterology" 4

For the prebiotic portion, it was demonstrated that 10 $\mathrm{g} /$ day of FOS and optimal dose is well tolerated, but $4 \mathrm{~g} /$ day of FOS or inulin is the minimum required to promote growth of bifidobacteria and, moreover, that the use of $14 \mathrm{~g} /$ day or more of inulin can cause intestinal discomfort ${ }^{16}$.

Some individuals may experience side effects related to the ingestion of probiotics due to the death of pathogens in the gut environment, as they release toxic cell products ("dieoff reaction"). In such cases, one should persist in the use of probiotics for which there is improvement in symptoms. Was noticed a slight increase in gas production, abdominal discomfort and even, in rare cases, diarrhea which resolved spontaneously by time ${ }^{2,4,12}$.

\section{CONCLUSION}

Symbiotic behave differently and positively in various pathological situations

\section{REFERENCES}

1 Bengmark S, Urbina JJ. O. Simbióticos: uma nueva estratégia em el tratamiento de pacientes críticos. Nutrición Hospitalaria. 2005; 20(2): 147-156

2 Delcenserie, V., et al., Immunomodulatory effects of probiotics in the intestinal tract. Curr Issues Mol Biol, 2008. 10(1-2): p. 37-54.

3 Denipote, F.G., E.B. Trindade, and R.C. Burini, Probiotics and prebiotics in primary care for colon cancer. Arq Gastroenterol, 2010. 47(1): p. 93-8.

4 Fooks, L.J. and G.R. Gibson, Probiotics as modulators of the gut flora. Br J Nutr, 2002. 88 Suppl 1: p. S39-49.

5 Gaudier E, Michel C, Segain JP, Cherbut C, Hoebler C. The VSL\#3 probiotic mixture modifies microflora but does not heal chronic dextran-sodium sulfate-induced colitis or reinforce the mucus barrier in mice. J Nutr. 2005;135:2753-61. 
6 Gianotti L. et al A randomized double-blind trial on perioperative administration of probiotics in colorectal cancer patients World J Gastroenterol 2010 January 14; 16(2): 167-175.

7 Gibson GR, Roberfroid MB. Dietary modulation of the human colonic microbiota: Introducing the concept of prebiotics. Journal of Nutrition 1995; 125: 1401-1412.

8 Gil A, Bengmark S. Control biocológico y nutricional de la enfermedad: prebióticos, probióticos y simbbióticos. Nutrición Hospitalaria. 2006; 21: 73-86.

9 Gillor, O., A. Etzion, and M.A. Riley, The dual role of bacteriocins as anti- and probiotics. Appl Microbiol Biotechnol, 2008. 81(4): p. 591-606.

10 Hord, N.G., Eukaryotic-microbiota crosstalk: potential mechanisms for health benefits of prebiotics and probiotics. Annu Rev Nutr 2008. 28: p. 215-31.

11 Horvat M, Krebs B, Potrc S, Ivanecz A, Kompan L. Preoperative synbiotic bowel conditioning for elective colorectal surgery. Wien Klin Wochenschr. 2010 May;122 Suppl 2:26-30.

12 Organização Mundial de Gastroenterologia (OMGE). Guias práticos: Probióticos e Prebióticos, 2011. Disponível em http:// www.worldgastroenterology.org/assets/export/userfiles/ Probiotics_FINAL_pt 2012.pdf

13 Park, J. and M.H. Floch, Prebiotics, probiotics, and dietary fiber in gastrointestinal disease. Gastroenterol Clin North Am, 2007. 36(1): 47-63.

14 Rafter J. Probiotics and colon cancer. Best Pract Res Clin Gastroenterol. 2003;17:849-59.

15 Rayes, N., et al., Effect of enteral nutrition and synbiotics on bacterial infection rates after pylorus-preserving pancreatoduodenectomy: a randomized, double-blind trial. Ann Surg, 2007. 246(1): p. 36-41.
16 Roberfroid MB. Prebiotics and Probiotcs: are they function foods? American Journal Nutrition. 2000; 71: 168-187.

17 Ruemmele, F.M., et al., Clinical evidence for immunomodulatory effects of probiotic bacteria. J Pediatr Gastroenterol Nutr, 2009. 48(2): 126-41.

18 Saad SMI. Probiótico e Prebiótico: o estado da arte. Rev. Brasileira de Ciências Farmacêuticas. 2006; 42: 01 - 16

19 Saavedra JM. Clinical applications of probiotic agents. Am J Clin Nutr 2001; 73(suppl) :1147S-51S.

20 Santos FL et al. Utilização de Probióticos na Redução da Anemia Ferropriva. Diálogos \& Ciências: Revista de Rede de Ensino da FTC. 2008; 7 (2): 13-22.

21 Stefe CA, Alves MAR, Ribeiro RL. Probióticos, Prebióticos e Simbióticos - Artigo de Revisão. Revista Saúde e Ambiente. 2008; 1 (3): 16-33.

22 Tanaka, et al. Impact of perioperative administration of synbiotics in patients with esophageal cancer undergoing esophagectomy: A prospective randomized controlled trial. Surgery. 2012 . Nov; 152(5) :832-42.

23 Usami $M$, et al. Effects of perioperative synbiotic treatment on infectious complications, intestinal integrity, and fecal flora and organic acids in hepatic surgery with or without cirrhosis. JPEN J Parenter Enteral Nutr. 2011 May;35(3):317-28.

24 Van Santvoort HC et al. Probiotics in surgery. Surgery. 2008 Jan;143(1):1-7. Epub 2007 Nov 8.

25 Willian M, Mabel A, Alberto B. Probióticos, Prebióticos y Simbióticos en pacientes críticos. Revista Brasileira de Nutrição Clínica. 2006; 21:155-162. 